ular instances. Solid fuel will be compelled to carry the main load for domestic use for many years to come, if only because in this form sufficient stocks can be provided to meet peak loads ; for continuous space-heating of domestic premises, the most efficient appliances are solid-fuel closed or closable fires, and gas fires with convection.

After reviewing technical considerations affecting uses, the report passes to discussion of the possibilities of tariff co-ordination as a means for securing the best use of the national fuel resources of Britain, but without being able to lay down any novel basis. In order that consumers' choice of fuel coincides with national interest regarding resources and smoke abatement, close attention should be paid to the tariff structure of individual fuel supply industries; subject to certain exceptions to cover promotional tariffs and the uneconomical consumer, tariffs should be closely related to cost of production and supply. Special importance is attached to regulation of coal prices ; relative prices for various grades and qualities must exert strong influence on trend of consumption and rate of development of the gas and electricity industries. The report recognizes the difficulties involved, and proposes tariff commissions for individual industries, guided by a national authority, probably the Ministry of Fuel and Power ; while unrestricted price competition is undesirable, administrative and technological competition has on the whole been of great benefit. There is a serious shortage of fuel technologists and the knowledge of the general public is small.

Even if the report leaves one a little in the air, it is invaluable at the present moment; it will serve for some time as the most readily available guide. Reference may perhaps be made to the remarkable statement on page 131 : "the earth's internal store of thermal energy is dependent for its maintenance on solar radiation"; and an omission in discussing possible future trends is reference to the gas turbine, for opinion recently expressed is that the raw coal turbine looks to most engineers a likely practical proposition for industrial service years ahead of atomic energy.

D. T. A. ToWNEND

\section{UNIVERSITY OF PRAGUE SEXCENTENARY CELEBRATIONS}

\section{By DR. GERALD DRUCE}

$\mathrm{T}$ HE six hundredth anniversary of the founding of the Charles University of Prague was cele. brated during the week commencing April 4. The precise date of its foundation is usually given as April 7, 1348, the day on which Charles, as King of Bohemia, issued his charter setting out the reasons for the institution of a seat of higher learning in the Czech capital. Until 1355, when the Carolinum was ready, tuition had to be given in religious buildings and in private houses that had previously served as Latin schools. The original building, enlarged and renovated, still serves for important University functions and was used for some of this year's ceremonies. For the general gatherings use was made of the large Vladislav Hall of the Hradcany Castle, which is capable of seating several thousands.

The first assembly was mainly for Czechoslovak participants, and included, as well as members of the
University, several Cabinet Ministers, prominent ecclesiastics, authors and representatives of the arts and sciences, workers' educational associations and students. The Czechoslovak Premier, Mr. Klement Gottwald, reminded the assembly that during its long history the University had given the world many great men of science and thinkers and that it entered upon its seventh century at a time of considerable social and economic change from which, it is hoped, a better world is being born. In such a world the University will have a still greater mission to fulfil since more scientific men and other scholars than ever before will be needed.

Prof. Bohumil Bydžovský, rector of the University, dealt at length with the University's significance for the nation's cultural and intellectual life. "For us the Carolinum is a symbol of the struggle for truth and for spiritual and ethical perfection and progress.' H.e stressed the contributions of John Hus and of T. G. Masaryk at different stages of its history. Prof. Z. Nejedily, Minister for Education and president of the Czech Academy, pointed out that the University has always been associated with national aspirations and its influence to-day is as great as ever, and so are the tasks before it.

Messages of congratulation were given by Profs. Seifert and Ryšaví respectively, on behalf of the sister University of Brno and the Prague Technical College, and by a representative of the students.

On the actual anniversary, the hall was filled with distinguished people and students when the procession of foreign delegates, the rector, members of the Senate, the deans and professors of the Charles University and of the other Czechoslovak universities entered. The rector escorted President Bent to his seat, welcoming the visitors in short speeches in four languages, referring again to the University's part in the nation's historical evolution. He mentioned its early contacts with other universities, especially those of Paris and Oxford, expressing gratitude to Oxford in particular for allowing Czech students to complete their studies there when the Czech universities were closed in 1939. He expressed his deep regret that British universities and those of some other countries had not accepted the invitations to participate in this historic ceremony.

In presenting the renewed charter, written on parchment by Prof. J. Benda of the School of Fine Arts, to replace the original that disappeared during the German occupation, President Ben€ š pointed out how moral and political issues profoundly affected the fate of seats of learning, which could always be found on the side of recognized truth, liberty and morality. It was from the University that so many honorable and wise men arose to lead the nation in both glorious and difficult times; but the Charles University had never been able to celebrate its centenaries in peace and tranquillity. Its first centenary occurred when King George of Pod rbrady was vainly trying to set up the first league of nations. In 1548 the first Czech revolt against the Habsburgs was being heavily suppressed. The Peace of West. phalia in 1648 followed the Thirty Years War that had devastated and depopulated the kingdom, then in bondage with the University in foreign hands. The year 1748 fell between two more wars that were disastrous for the Czech people, apart from the added contemporary dangers of Austrian measures of centralization and Germanization. Finally, the year 1848, which brought the beginnings of constitutionalism to the Slavs, was also one of storms, and not 
even to-day are the celebrations taking place in tranquil times. Three years after the most terrible war in history there is still no such peace as is longed for so ardently. If this human longing, accompanied by freedom of belief, science, thought and profession, is to be fulfilled, President Benes said, it is even more necessary to realize a universal freedom of the spirit. This freedom, founded on man's respect for man and on the common tolerance traditionally associated with the Charles University, will lead once more to a happy prosperity and a truly happy future.

The preamble in Czech and the Latin text of the renewed charter were read out by Prof. Nejedly.

Prof. Jean Sarrailh, rector of the Sorbonne, gave a congratulatory address on behalf of the visitors. He referred to the links between Prague and other universities, and mentioned that the Czech scholar, Albertus Ranconis, came from the Charles University to Paris, where he was rector of the Sorbonne in 1355. Educated at Paris, Charles IV had carried French educational traditions back to Bohemia, where Hus was soon to make a stand for religious freedom and social justice. The successful extension of learning was interrupted by the Habsburgs, who even banned the use of the Czech language; and it was not until 1918 that free cultural activities could be resumed at the Charles University. Since then, Czech culture and civilization has become better known in France and elsewhere through the work of Prof. Ermest Denis, who also enabled Czech pupils to attend high schools at Nîmes and Dijon, where Eduard Ben€కs studied. The development of Czech culture was again interrupted by the German occupation in 1939; but no force can for ever prevail over the spirit, and the University is again happily in Czech hands. Prof. Sarrailh concluded, "Ainsi, comme au Moyen-Age, votre Université remplira son rôle international. Fidèle au grand rêve de Georges de Podøbrady, le plus populaire de vos rois, elle travaillera à l'avènement de la paix universelle et restera le temple de science et de progrès humain qu'avait voulu faire d'elle son fondateur'.

A students' representative, M. Grohmann, spoke extempore in four languages, before the delegates of foreign universities presented illuminated scrolls to the rector.

On the following day, honorary doctorates were conferred at the Carolinum on about forty distinguished savants representing all branches of learning, including science and medicine. The theological faculty awarded a degree to Cardinal Mercatti, archivist at the Vatican; the medical faculty gave degrees to Prof. R. Leriche of the College de France, Prof. L. A. Orbelli of Leningrad and Prof. P. D. White of Harvard. The awards of the philosophical faculty went mainly to specialists in Slavonic subjects, such as Prof. Andre Mazon of Paris and Prof. Ali A. Siassi, rector of Teheran University. The natural science degrees were conferred upon Prof. P. E. Eskola of Helsinki, Prof. B. Isačenko of Moscow, Prof. S. J. Jakovljevič of Belgrade, Prof. L. Rủžička of Zurich, Prof. W. Sierpinski of Warsaw and Prof. S. I. Vavilov of Moscow. The only Czechoslovak recipient was the Minister of Education, Prof. $Z$. Nejedly, who recalled how he had graduated in the same hall forty-eight years earlier. A number of the degrees were conferred in absentia, and Prof. Nesmeyanov, rector of the University of Moscow and well known for his researches on organo-metallic compounds, in accepting them for his absent Russian colleagues, replied for the recipients.
The formal ceremonies of the sexcentenary celebrations terminated on April 9 at the Vladislav Hall. The six deans of the University gave brief accounts of the history and work of their respective faculties, and Prof. Bydžovský concluded by thanking those whose work and presence had made the occasion such a success. It had been a landmark in the history of the University and of Czechoslovak learning, and had served to strengthen the bonds of friendship between men of science and culture throughout the world.

At the Clementinum and in the Industrial Art Museum there were exhibitions of books, historic documents, incunabulce, paintings and other objects that are rarely available for the public to see. These included various fourteenth century Bulls and decrees relating to the University, the original Kutná Hora decree dated 1409 of Wenceslas IV, a letter from the rector in 1414 protesting against the burning of books, fourteenth-century registers of students, the matriculation lists for 1372-73 and a manuscript written by H.us as rector in 1401-2.

The "Letter of Majesty" extracted from Rudolf II in 1609 which conferred greater liberty on the University was on view, and showed the scissor cuts of Ferdinand II, who revoked it in 1620 . There were many early scientific tracts, diplomas, and early printed books. Most of the portraits were of early scholars and naturalists such as Mikan, Bohadsch, Prochazka, Marcus Marci, Bolzano, Krombholz, the Presls, Dobrovksý and Şafař́k. 'Tycho Brahe's portrait, sextant and "Tabulre sinuum" were among the other interesting objects on view. The books included the earliest Czech works in science and mathematics, the 1879 edition of Goll's "Development of the English Parliament", which is 'said to have greatly influenced T. G. Masaryk, and Benes's 1909 dissertation for his degree ("Developments of Political Individualism in the History of Modern Philosophy"). Among the historical works was the manuscript of Bohuslav Balbin, that waited a century before it was printed as "Bohemia Docta" in 1780 . Another curiosity was the 1793 bilingual announcement of Pelcl's lectures (the first to be given in Czech since 1620).

The informal arrangements that followed the official proceedings included excursions to Lany (to see the simple but impressive tomb of President Masaryk and his son, Dr. Jan Masaryk), Lidice, Karlstein (the castle built by Charles IV as a retreat from the cares of State and for the custody of the erown jewels), Kutná Hora and Hradec Kralové. It was at Kutna Hora, a medieval mining town and royal seat, in 1409 that Charles's son, Wenceslas IV, signed the famous decree expressly laying down the Czech character of the Charles University. Receptions in connexion with the celebrations were given by the Rector of the Charles University, the Lord Mayor of Prague and by the Minister of Foreign Affairs, Mr. V. Clementis. Mr. Clementis received no less than nine hundred guests in the large reception halls of the Czernin Palace that serves for the Foreign Ministry to-day. A special performance of Smetana's opera "The Bartered Bride" was given at the National Theatre, and the students also arranged some festivities, one anachronistic tableau representing Charles IV riding on a motor-cycle. Unfortunately the strain of the celebrations told upon the sixtyeight years old rector, Prof. Bydžovský, who was taken to hospital two days after the ceremonies ended. 